\title{
Local Responses to Federal Grants: Evidence from the Introduction of Title I in the South
}

\author{
By Elizabeth U. Cascio, Nora Gordon, and Sarah Reber
}

\section{Online Appendix A: Data}

\section{Sources and Variables}

\section{I.A School Finance and Enrollment Data}

Our analysis of the fiscal impacts of Title I relies on district-level data on current expenditure and revenue by source (local, state, and federal). These data were hand-entered from annual reports of state departments or superintendents of education and are available on an annual basis between 1961 and 1969 with several exceptions. Georgia did not publish any relevant data for 1962 (use 1961), 1964 (use 1963), 1966 (use 1965), and 1969 (use 1970). Georgia also did not publish revenue by source in 1968 (use 1967). Louisiana did not publish any relevant data for 1967 (use 1966). ${ }^{1}$ Real per-pupil values of the finance variables were created by dividing by total enrollment from the same year, drawn from the same source, then converting to real 2009 dollars using the CPI-U.

\section{I.B High School Dropout Data}

Our analysis of the effects of Title I on educational attainment uses the 1960 to 1970 change in the high school dropout rate of 18 and 19 year olds as the dependent variable. We constructed this outcome using county-level tabulations of population characteristics by single year of age (ages 15 to 19), race (white, black/African American, other), and year, produced for us by the Census Bureau using the sample detail files from the 1960 and 1970 Censuses. The numerator of the dropout rate in a given Census year is the number of 18 and 19 year old residents of a county of a given race who have less than twelve years of completed education and are not enrolled in school. The denominator is the total number of 18 and 19 year old residents of that county of that race with education reported.

We perform a falsification check using the 1960 to 1970 change in the high school dropout rate of county residents aged 25 and over, which we constructed in a similar fashion using published Census tabulations of the total population (both years), the non-white population in 1960, and black population in $1970 .{ }^{2}$ Here, the numerator of the dropout rate in a given Census year is the number of residents age 25 and over with less than twelve years of completed education, and the denominator is the total number of residents age 25 and over with education reported. We handentered the 1960 data from Table 83 and Table 87 of U.S. Census (1963) and downloaded 1970

\footnotetext{
${ }^{1}$ Alabama Department of Education (various years), Florida State Superintendent of Public Instruction (various years), Georgia State Department of Education (various years), Mississippi State Department of Education (various years), North Carolina Education Association (various years), South Carolina State Department of Education (various years), State Department of Education of Louisiana (various years), Tennessee Department of Education (various years), Virginia State Board of Education (various years).

${ }^{2}$ When tabulations for either non-whites or blacks are reported, we obtain figures for the white population by taking the difference between total and non-white (in 1960) or between total and black (in 1970). When tabulations for non-whites or blacks are not reported (due to small population), we use the totals as figures for the white population.
} 
data from the National Historical Geographic Information System (Minnesota Population Center 2004). We retrieved data on 1950 and 1960 school enrollment rates of 16 and 17 year olds from Historical Census Browser (2004).

\section{I.C Title I Eligibility Data}

Our identification strategy relies on an estimate of initial district eligibility for Title I funds. Formula amounts were established by the federal government at the county level. States determined the methodology for dividing the formula amounts among districts within counties, based on available data at the sub-county level. We do not know data sources used for these divisions, but we do observe the actual divisions in the first fall of the program in 1965, tlalloc $_{d, 1965}$ (U.S. Senate 1967). We also observe county-level counts of 5-17 year olds eligible

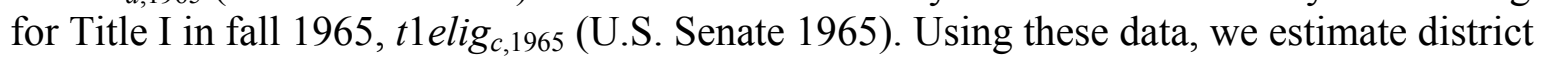
counts of Title I eligible children for 1965, t1elig $_{d, 1965}$ as

$$
\text { t1elig }_{d, 1965} \approx t 1 \text { elig }_{c, 1965} \times \frac{\text { tlalloc }_{d, 1965}}{\sum_{d \in c} \text { t1alloc }_{d, 1965}}
$$

or with the 1965 county-level eligibles times the share of the 1965 county Title I formula amount the district was allocated (i.e., what the district would have received if it were in compliance with the minimal desegregation requirements for CRA compliance at the time). ${ }^{3}$ We then define the "initial" child poverty rate as $t$ elig $_{d, 1965} / e n r_{d, 1960}$, where $e n r_{d, 1960}$ represents 1960 district enrollment. If the effective poverty rate for distribution of Title I funds (based on current enrollment and current eligibility) were roughly equal to the initial child poverty rate, the change between 1964 and any year from 1965 to 1969 in the coefficient on child_poverty in regressions for per-pupil federal revenue should be equal to the amount received for districts for each eligible child - the "state factor" - in the Title I formula. The state factor for 1969 used in the paper is from U.S. Senate (1970).

\section{I.D Other District- and County-Level Covariates}

1. 1960 black enrollment share (district): For most states, this variable is constructed from 1960 data on enrollment by race in the school finance publications cited in Section I.A of this Appendix. ${ }^{4}$ We estimated this variable for North Carolina using district-level data from Southern Education Reporting Service $(1964,1966)$.

2. Thurmond vote share in the 1948 Presidential Election (county): The county-level percent of votes cast for Strom Thurmond in the 1948 Presidential election was drawn from ICPSR Study No. 8611 (Clubb, Flanigan, and Zingale 2006).

\footnotetext{
${ }^{3}$ Note that, in reality, there were two categories of Title I eligibles in 1965: (1) children aged 5 to 17 in families with incomes less than $\$ 2000$ in the 1960 Census; (2) children in families receiving AFDC in excess of $\$ 2000$. We refer to all Title I eligibles as being from group (1) for ease of explanation, as the vast majority of eligibles are in indeed in this group in our sample.

${ }^{4}$ We use the enrollment measure most consistently reported within the state over time. All states except Georgia and North Carolina report fall enrollment or registration or average daily membership. To make these states' enrollment figures more comparable to those for other states, we multiply the enrollment concept reported (average daily attendance, or ADA) by the statewide average ratio of fall enrollment to ADA reported in HEW (1967).
} 
3. Poorest Counties in 1960 (county): Data on whether a county was one of the 300 poorest counties in 1960, which was expected to have received special grant-writing assistance for Head Start (Ludwig and Miller 2007), was generously provided to us by Jens Ludwig and Douglas Miller. The poverty rate used in this determination was also provided to us, and is distinct from (but positively correlated with) that used for dissemination of funds under Title I (see section I.C of the Data Appendix).

4. 1970 Dissimilarity Index (district): The formula for the dissimilarity index is given by:

$$
\frac{\sum_{i \in d} e n r_{i}\left|\% b l_{i}-\% b l_{d}\right|}{2 \times e n r_{d} \times \% b l_{d} \times\left(1-\% b l_{d}\right)}
$$

where $e n r_{i}$ is total enrollment in school $i, e n r_{d}$ is the enrollment in district $d$ (summing across all schools), $\% b l_{i}$ is the percent of total enrollment in school $i$ that is black, and $\% b l_{d}$ is the black enrollment percent in district $d$. It can be interpreted as the share of students who would have had to change schools to replicate the racial composition of the district in each school. We construct a dissimilarity index for all available districts as of 1970 using computer-coded microdata on enrollment by race at the school level from a 1970 survey (HEW 1972) conducted by the Office for Civil Rights, housed at UCLA and converted from binary to ascii format by Ben Denckla and Sarah Reber. Not all districts are represented in this survey, so we lose some districts when looking at the dissimilarity index as an outcome. ${ }^{5}$

5. Pre-VRA Black Voter Registration Rate (county): James Alt generously provided available data on black voter registration rates in the early 1960s for all states represented in our sample except Virginia. We hand-entered pre-VRA voter registration rates in Virginia from Table 12 of U.S. Commission on Civil Rights (1968).

6. Outlays on Federal Programs (county): Changes (1962 to 1969) in per-capita federal outlays to counties for public assistance (less food stamps), Medicare, Medicaid, and retirement and disability programs were constructed using data from the Regional Economic Information system, generously provided to us by Douglas Almond, Hilary Hoynes, and Diane Schanzenbach. Federal outlays to counties for Head Start in 1968 were drawn from National Archives data and generously provided to us by Jens Ludwig and Douglas Miller.

\section{Estimation Sample}

\footnotetext{
${ }^{5}$ Most of these districts are smaller districts in Tennessee. The survey included all districts "eliminating racially dual school systems under terms of voluntary plan agreements with [HEW] or under Federal court order regardless of school district enrollment size" (with the exception of such districts in Tennessee and Texas). It also included all districts with at least 3000 enrollment and smaller districts with the following probabilities: $75 \%$ for districts with 1200 to 2999 students, $50 \%$ for districts with 600 to 1199 students, $25 \%$ for districts with $300-599$ students, and $0 \%$ for districts with less than 300 students.
} 
School districts both consolidate and, less commonly, split apart during our sample period. We use the state school finance data referenced above to establish a history of these reorganizations and limit our working sample to districts that do not experience reorganization between 1961 and 1969 (1011 districts across nine Southern states). Our estimation sample includes all districts in this sample with data available for the fiscal outcomes and the following pre-existing characteristics - the 1960 child poverty rate, 1960 black enrollment share, 1960 enrollment, 1948 Thurmond vote share, and whether the district was in one of the 300 poorest counties in 1960 (973 districts). We also trim districts from the sample for which changes in any of the four key outcomes over 1961 to 1964 or 1964 to 1969 lies more than 3.5 standard deviations away from the state-specific mean. Our final sample includes 910 districts.

\section{References}

Alabama Department of Education.Various Years. "Annual Report for the Scholastic Year Ending ... and for the Fiscal Year Ending ...: Statistical and Financial Data." Montgomery, AL.

Clubb, Jerome M., William H. Flanigan, and Nancy H. Zingale, Electoral Data for Counties in the United States: Presidential and Congressional Races, 1984-1972 [Computer file], Compiled by Jerome M. Clubb, William H. Flanigan, and Nancy H. Zingale, ICPSR08611-v1, (Ann Arbor, MI: Inter-university Consortium for Political and Social Research, 2006-11-13).

Florida State Superintendent of Public Instruction. Various years. "Ranking of the Counties." Research Report, Division of Research. Tallahassee, FL.

Georgia State Department of Education. Various years. "Annual Reports of the Department of Education to the General Assembly of the State of Georgia." Atlanta, GA.

Historical Census Browser. 2004. Retrieved April 12, 2012, from the University of Virigina, Geospatial and Statistical Data Center: http://mapserver.lib.virginia.edu/collections/.

Minnesota Population Center. 2004. "National Historical Geographic Information System: Prerelease Version 0.1." Minneapolis, MN: University of Minnesota. http://www.nhgis.org.

Mississippi State Department of Education. Various years. "Biennial report and recommendations of the State Superintendent of Public Education to the legislature for the scholastic year." Jackson, MS: State Superintendent of Public Education.

North Carolina Education Association. Various years. "Per Pupil Expenditures for Current Expense: Information Provided by Division of Statistical Services State Department of Public Instruction." Raleigh, NC.

South Carolina State Department of Education. Various years. "Annual Report of the State Superintendent of Education of the State of South Carolina." Columbia, SC. 
Southern Education Reporting Service. 1964. "A Statistical Summary, State By State, of School Segregation-Desegregation in the Southern and Border Area from 1954 to the Present." Fourteenth revision. Nashville, TN: Southern Education Reporting Service.

Southern Education Reporting Service. 1967. "A Statistical Summary, State By State, of School Segregation-Desegregation in the Southern and Border Area from 1954 to the Present." Sixteenth revision. Nashville, TN: Southern Education Reporting Service.

State Department of Education of Louisiana. Various years. "Financial and Statistical Report." Baton Rouge, LA.

Tennessee Department of Education. Various years. "Annual Statistical Report of the Department of Education.” Nashville, TN.

U.S. Commission on Civil Rights. 1968. "Political Participation: A Study of the Participation of Negroes in the Electoral and Political Processes in 10 Southern States Since Passage of the Voting Rights Act of 1965." Washington, DC: U.S. Government Printing Office.

U.S. Department of Commerce, Bureau of the Census. 1963. "Census of Population: 1960. Volume I: Characteristics of the Population. Washington, DC: U.S. Government Printing Office.

U.S. Department of Health, Education, and Welfare, Office of Education. 1967. "Statistics of State School Systems 1963-64.” Washington, DC: U.S. Government Printing Office.

U.S. Department of Health, Education, and Welfare. Office of Education. 1972. Directory of Public Elementary and Secondary Schools in Selected Districts: Enrollment and Staff by Racial/Ethnic Group, Fall 1970. Washington, DC: US Government Printing Office.

U.S. Senate. Committee on Labor and Public Welfare. Subcommittee on Education. 1965. "Maximum Basic Grants-Elementary and Secondary Education Act of 1965 (Public Law 81874, Title II, and Public Law 89-10, Title I).” Washington, DC: U.S. Government Printing Office.

U.S. Senate. Committee on Labor and Public Welfare. Subcommittee on Education. 1970. "Allocation of Funds Under Title I of the Elementary and Secondary Education Act of 1965, As Amended, Fiscal Year 1970.” Washington, DC: U.S. Government Printing Office.

Virginia State Board of Education. Various years. "Annual Report of the Superintendent of Public Instruction of the Commonwealth of Virginia." Richmond, VA.

\section{Online Appendix B: Supplementary Analyses}

\section{Cost benefit analysis}

This section describes how we approximate the labor market returns to the additional educational attainment induced by Title I spending. We view this calculation as providing a rough 
approximation of the lower bound of potential benefits, as it ignores likely additional unmeasured private and social returns to this schooling - for example, improvements in health, reductions in criminal behavior, and increased civic participation. Nor do we include the efficiency costs associated with raising the revenue used to fund the program.

Because we do not find a significant impact on educational attainment for blacks, the benefits in this calculation come solely from whites; the costs include all expenditures including those nominally allocated to black students. We estimate the benefits by applying the rate of return to additional schooling for annual wage income over one's career, and by multiplying this present discounted value by our estimated change in probability that one graduates from high school. We assume a ten percent rate of return to an additional year of schooling, in the middle of the range of estimates in the relevant literature, and a five percent discount rate. We calculate the mean annual wage income from the 1970 Census, using white men and women ages 20-50 in our sampled states who finished tenth grade but did not graduate from high school. This mean (\$33,132 in 2009 dollars - all figures going forward are in 2009 dollars as well) is estimated unconditional on labor market participation; the mean conditional on positive earnings is $\$ 38,033$. Our preferred specification for outcomes results (see Table 7, Panel A, Column 1) estimates that $\$ 100$ in Title I-induced spending per pupil yields a 3.46 percentage point decrease in the likelihood of high school dropout. For one year's wages, the estimated expected additional return from $\$ 100$ of Title I revenue is \$49 of annual wage income per person.

We estimate the costs of the program based on two different definitions of cost: (1) federal dollars spent on intergovernmental grants to school districts (this includes transfers to local consumption whose benefits we disregard but is what the federal government would use in calculating returns on its grants); and (2) current educational spending by school districts (relevant for the more general question of how money matters in the production of education). The estimates in Table 7, Panel A, Column 1 correspond to the latter concept.

From the district (current expenditure) perspective:

In our sample, the typical white student lived in a district with 76 percent white enrollment. Assuming that funds were distributed equally across students regardless of race, it would cost approximately $\$ 132$ per pupil to spend $\$ 100$ per white pupil. We estimate this using data for 1969, so the cohort generating this result on average received Title I funding for five years to produce this attainment gain. We therefore compare our estimated benefits (associated labor market return expected from additional \$100 Title I revenue per pupil per year) with a cost of $\$ 132 * 5=\$ 660$. After 23 years of work, the present discounted value of additional wages exceeds this amount.

From the federal (Title I revenue including crowded out funds) perspective:

We find that one dollar of Title I revenue per pupil increases current expenditure per pupil by $\$ 0.50$ (Table 3, Column 3). \$132 of spending per pupil (the cost of spending $\$ 100$ per white pupil) therefore costs $\$ 264$ per pupil in federal revenue $(264=132 / .5)$ per year or $\$ 1320$ over five years. Considering these higher costs, the five-year intervention would not be cost-effective in the average worker's lifetime; again, this disregards all other benefits of the increased education spending and increased consumption due to crowd out. 


\section{Income elasticity calculation}

We find that one dollar of Title I revenue per pupil increases current expenditure per pupil by $\$ 0.50$ (Table 3, Column 3). We want to know how much spending would have been expected to increase in response to Title I based on the income elasticity of demand for education spending.

The increase in spending on education due to the grant is

\section{AddlSpending $=$ CounterfactualSpending $\times \eta \times \% \Delta$ IncomeDuetoGrant}

where $\eta$ is the (assumed) income elasticity of demand for education spending.

To estimate CounterfactualSpending for 1969 (what education spending would have been without Title I), we assume that in the absence of Title I, spending per pupil would have increased in line with income growth: We apply the assumed income elasticity of demand and the observed growth in median family income in the county ${ }^{6}$ to pre-program (1964) per-pupil current expenditure:

\section{CounterfadualSpendingPerPupil $_{69}=$ SpendingPePupil $_{64} \times \eta \times \% \Delta$ MedianFamiyIncome $_{64-69}$}

We then multiply by enrollment to get total counterfactual spending:

$$
\text { CounterfactualSpending }_{69}=\text { CounterfactualSpendingPerPupil }_{69} \times \text { Enrollment }_{69}
$$

To estimate \% IncomeDuetoGrant, we divide the Title I grant by the number of families (to get the additional income per family implied by the grant, as if the grant were distributed as cash) and then divide by median family income in 1969:

$$
\% \Delta \text { IncomeDuetoGrant }=\frac{\text { TotalTitleIGrant }_{69} / \text { NumberFamilies }_{69}}{\text { MedianFamilyIncome }_{69}}
$$

We can then calculate the additional spending the Title I grant would be expected to generate for each county. To compare that to our coefficients, which indicate how much additional spending was generated for each additional dollar of Title I revenue, we divide the implied additional spending by the total Title I grant. Using this method, we calculate the expected additional spending for a range of income elasticities reported in the literature, 0.40 to 0.65 (Fisher and Papke, 2000). These estimates are consistent with spending increases of $\$ 0.12$ to $\$ 0.19$ per dollar of Title I revenue.

\footnotetext{
${ }^{6} \mathrm{We}$ assume that half the change in median family income at the county level (obtained from the County and City Data Book) from 1960 to 1970 occurred from 1964 to 1969.
} 


\section{Online Appendix C: Additional Results}

TABLE A1 - Heterogeneity In THE FisCAL AND DESEGREGATION RESPONSE TO THE INTRODUCTION OF TITLE I BY QUARTILE OF SCOPE FOR LOCAL OFFSET

\begin{tabular}{ccccc}
\hline \hline & \multicolumn{3}{c}{ Dependent Variable: } \\
& & & \\
$\Delta$ Per-pupil & $\Delta$ Per-pupil & $\Delta$ Per-pupil & \\
Current & State & Local & \\
Expenditure, & Revenue, & Revenue, & Dissimilarity \\
1964 to & 1964 to & 1964 to & Index, \\
1969 & 1969 & 1969 & 1970 \\
$(1)$ & $(2)$ & $(3)$ & $(4)$ \\
\hline
\end{tabular}

$\Delta$ Per-pupil Federal Revenue,

1964 to 1969

First-stage Partial F-stat on

Instr.

Number of districts

$\Delta$ Per-pupil Federal Revenue,

1964 to 1969

First-stage Partial F-stat on

Instr.

Number of districts

$\Delta$ Per-pupil Federal Revenue,

1964 to 1969

First-stage Partial F-stat on

Instr.

Number of districts

$\Delta$ Per-pupil Federal Revenue,

1964 to 1969

First-stage Partial F-stat on

Instr.

Number of districts
A. Districts in Top Quartile (Least Scope for Local Offset)

$\begin{array}{cccc}0.881 * * * & 0.0101 & -0.0262 & 0.000151 \\ (0.167) & (0.0886) & (0.101) & (0.000121) \\ 35.29 & 35.29 & 35.29 & 32.79 \\ 227 & 227 & 227 & 207\end{array}$

B. Districts in Third Quartile
$0.671 * *$

(0.293)

28.01

228

0.395

(0.265)

26.61

227
$-0.0505$

(0.141)

$-0.156$

(0.190)

28.01

28.01

228

228

C. Districts in Second Quartile

$0.318^{* *} \quad-0.568 * *$

$(0.153) \quad(0.254)$

26.61

227
$-2.87 \mathrm{e}-05$

(0.000140)

21.89

212

$-3.97 \mathrm{e}-06$

(0.000181)

22.45

213
D. Districts in First Quartile (Most Scope for Local

$$
\text { Offset) }
$$

$\begin{array}{cccc}-0.0801 & -0.123 & -0.583^{*} & 8.02 \mathrm{e}-05 \\ (0.281) & (0.157) & (0.309) & (0.000192) \\ 39.84 & 39.84 & 39.84 & 44.80 \\ 228 & 228 & 228 & 221\end{array}$

Notes: All dollar figures are in real 2009 dollars. Each column and panel presents coefficient estimates from a TSLS regression. All regressions include state dummies, 1960 black enrollment share, $\ln (1960$ district enrollment), an indicator that the district is in one of the 300 poorest counties in 1960, and indicators for quintiles of the Thurmond vote share. "Scope for local offset" is the ratio of the predicted per-pupil Title I grant in 1969 to predicted per-pupil local revenue in 1969 , the latter is the prediction given the district-specific linear trend over 1961 to 1964 . Standard errors (in parentheses) are clustered on county.

*** Significant at the 1 percent level, **Significant at the 5 percent level, * Significant at the 10 percent level. 
TABLE A2 —Descriptive Statistics On District Characteristics: By SCOPE FOR LoCAL OfFSET

\begin{tabular}{llccc}
\hline \hline & \multicolumn{3}{c}{ Districts with Low Scope for Offset } \\
\cline { 3 - 4 } & Mean & Std. dev. & Obs. \\
& $(1)$ & $(2)$ & $(3)$ \\
\hline
\end{tabular}

A. Districts with Low Scope for Offset

\author{
Child poverty rate, 1960 \\ State factor in Title I grant, 1969 \\ Black enrollment share, 1960 \\ District enrollment, 1960 \\ One of poorest 300 counties, $1960(=1)$ \\ Percent voting for Thurmond, 1948 \\ Black voter registration rate, early 1960s (percent) \\ Black/white dissimilarity index, 1970
}

Child poverty rate, 1960

State factor in Title I grant, 1969

Black enrollment share, 1960

District enrollment, 1960

One of poorest 300 counties, $1960(=1)$

Percent voting for Thurmond, 1948

Black voter registration rate, early 1960s (percent)

Black/white dissimilarity index, 1970

$\begin{array}{ccc}0.51 & 0.16 & 227 \\ 955 & 5.90 & 227 \\ 0.46 & 0.26 & 227 \\ 4,130 & 2,810 & 227 \\ 0.58 & 0.49 & 227 \\ 43 & 34 & 227 \\ 19 & 24 & 208 \\ 0.27 & 0.24 & 207\end{array}$

B. Other Districts

$\begin{array}{ccc}0.26 & 0.13 & 683 \\ 954 & 6.12 & 683 \\ 0.27 & 0.19 & 683 \\ 7,872 & 13,478 & 683 \\ 0.12 & 0.33 & 683 \\ 30 & 27 & 683 \\ 31 & 23 & 604 \\ 0.29 & 0.21 & 646\end{array}$

Notes: All dollar figures are in real 2009 dollars. Sample consists of school districts in 9 southern states: Alabama, Florida, Georgia, Louisiana, Mississippi, North Carolina, South Carolina, Tennessee, and Virginia. See Appendix A for description of estimation sample. 
TABLE W3A — REDUCED-Form AND TSLS ESTIMATES OF THE FISCAL RESPONSE TO THE INTRODUCTION OF TitLE I WEIGHTED BY 1960 ENROLLMENT

\begin{tabular}{|c|c|c|c|}
\hline & \multicolumn{2}{|c|}{$\underline{\text { Reduced Form }}$} & \multirow{2}{*}{$\begin{array}{c}\text { TSLS } \\
1964 \text { to } 1969 \\
\text { (3) }\end{array}$} \\
\hline & $\begin{array}{c}1961 \text { to } 1964 \\
\text { (1) }\end{array}$ & $\begin{array}{l}1964 \text { to } 1969 \\
\text { (2) }\end{array}$ & \\
\hline & \multicolumn{3}{|c|}{ A. $\Delta$ Per-pupil Federal Revenue } \\
\hline \multirow[t]{2}{*}{ Child Poverty Rate, 1960} & 16.32 & $1050.0^{* * *}$ & \\
\hline & $(10.36)$ & $(47.8)$ & \\
\hline \multirow[t]{3}{*}{ Black Enrollment Share, 1960} & $-15.57 * *$ & $61.35^{*}$ & \\
\hline & $(6.58)$ & $(37.24)$ & \\
\hline & \multicolumn{3}{|c|}{ B. $\Delta$ Per-pupil Current Expenditure } \\
\hline \multirow[t]{2}{*}{ Child Poverty Rate, 1960} & $-123.4^{*}$ & $517.8 * * *$ & \\
\hline & $(64.59)$ & $(108.9)$ & \\
\hline \multirow[t]{2}{*}{$\Delta$ Per-pupil Federal Revenue, 1964 to 1969} & & & $0.493 * * *$ \\
\hline & & & $(0.097)$ \\
\hline \multirow[t]{3}{*}{ Black Enrollment Share, 1960} & -67.20 & $552.2 * * *$ & $522.0^{* * *}$ \\
\hline & (77.83) & $(124.9)$ & $(118.8)$ \\
\hline & \multicolumn{3}{|c|}{ C. $\Delta$ Per-pupil State Revenue } \\
\hline \multirow[t]{2}{*}{ Child Poverty Rate, 1960} & -20.04 & 39.86 & \\
\hline & $(21.81)$ & $(43.83)$ & \\
\hline \multirow[t]{2}{*}{$\Delta$ Per-pupil Federal Revenue, 1964 to 1969} & & & 0.038 \\
\hline & & & $(0.042)$ \\
\hline \multirow[t]{3}{*}{ Black Enrollment Share, 1960} & $39.99 * *$ & $77.67 * *$ & $75.34^{* *}$ \\
\hline & $(19.69)$ & $(36.50)$ & $(38.21)$ \\
\hline & \multicolumn{3}{|c|}{ D. $\Delta$ Per-pupil Local Revenue } \\
\hline \multirow[t]{2}{*}{ Child Poverty Rate, 1960} & -70.09 & $-595.4 * * *$ & \\
\hline & $(50.57)$ & $(88.56)$ & \\
\hline \multirow[t]{2}{*}{$\Delta$ Per-pupil Federal Revenue, 1964 to 1969} & & & $-0.567 * * *$ \\
\hline & & & $(0.0926)$ \\
\hline \multirow[t]{2}{*}{ Black Enrollment Share, 1960} & 0.40 & $327.3 * * *$ & $362.1 * * *$ \\
\hline & $(47.24)$ & $(102.8)$ & $(117.5)$ \\
\hline First-stage Partial $F$-stat on instrument & & & 482.6 \\
\hline Number of districts & 910 & 910 & 910 \\
\hline
\end{tabular}

Notes: All dollar figures are in real 2009 dollars. All specifications include as controls state dummies and 1960 black enrollment share. The TSLS regressions in column (3) use the 1960 child poverty rate as an instrument for the 1964 to 1969 change in per-pupil federal revenue. Standard errors (in parentheses) are clustered on county.

*** Significant at the 1 percent level, **Significant at the 5 percent level, * Significant at the 10 percent level. 
TABLE W3B —REDUCED-Form AND TSLS ESTIMATES OF THE FISCAL RESPONSE TO THE INTRODUCTION OF TITLE I USING 1967 INSTEAD OF 1969 AS END YEAR

\begin{tabular}{|c|c|c|c|}
\hline & \multicolumn{2}{|c|}{$\underline{\text { Reduced Form }}$} & \multirow{2}{*}{$\begin{array}{c}\text { TSLS } \\
1964 \text { to } 1967 \\
\text { (3) }\end{array}$} \\
\hline & $\begin{array}{c}1961 \text { to } 1964 \\
\text { (1) }\end{array}$ & $\begin{array}{c}1964 \text { to } 1967 \\
\text { (2) }\end{array}$ & \\
\hline & \multicolumn{3}{|c|}{ A. $\Delta$ Per-pupil Federal Revenue } \\
\hline \multirow{2}{*}{ Child Poverty Rate, 1960} & 10.12 & $866.2 * * *$ & \\
\hline & $(6.702)$ & $(53.87)$ & \\
\hline \multirow{3}{*}{ Black Enrollment Share, 1960} & $-9.161 * *$ & $-63.83 *$ & \\
\hline & $(3.950)$ & $(38.42)$ & \\
\hline & \multicolumn{3}{|c|}{ B. $\Delta$ Per-pupil Current Expenditure } \\
\hline \multirow[t]{2}{*}{ Child Poverty Rate, 1960} & -59.30 & $313.6^{* * *}$ & \\
\hline & $(45.84)$ & $(74.98)$ & \\
\hline \multirow[t]{2}{*}{$\Delta$ Per-pupil Federal Revenue, 1964 to 1969} & & & $0.362 * * *$ \\
\hline & & & $(0.0795)$ \\
\hline \multirow[t]{3}{*}{ Black Enrollment Share, 1960} & -20.24 & $137.0^{* *}$ & $160.1 * * *$ \\
\hline & (49.37) & $(55.62)$ & $(49.12)$ \\
\hline & \multicolumn{3}{|c|}{ C. $\Delta$ Per-pupil State Revenue } \\
\hline \multirow[t]{2}{*}{ Child Poverty Rate, 1960} & 30.64 & $-64.72 *$ & \\
\hline & $(21.29)$ & $(36.43)$ & \\
\hline \multirow[t]{2}{*}{$\Delta$ Per-pupil Federal Revenue, 1964 to 1969} & & & $-0.0747 *$ \\
\hline & & & $(0.0423)$ \\
\hline \multirow[t]{3}{*}{ Black Enrollment Share, 1960} & -1.486 & 38.35 & 33.58 \\
\hline & $(19.10)$ & $(30.84)$ & $(29.65)$ \\
\hline & \multicolumn{3}{|c|}{ D. $\Delta$ Per-pupil Local Revenue } \\
\hline \multirow[t]{2}{*}{ Child Poverty Rate, 1960} & $-60.21 * *$ & $-307.6^{* * *}$ & \\
\hline & $(25.89)$ & $(49.62)$ & \\
\hline \multirow[t]{2}{*}{$\Delta$ Per-pupil Federal Revenue, 1964 to 1969} & & & $-0.355^{* * *}$ \\
\hline & & & $(0.0616)$ \\
\hline \multirow[t]{2}{*}{ Black Enrollment Share, 1960} & -33.32 & 33.94 & 11.28 \\
\hline & (20.98) & $(41.4)$ & $(40.75)$ \\
\hline First-stage Partial F-stat on instrument & & & 258.5 \\
\hline Number of districts & 910 & 910 & 910 \\
\hline
\end{tabular}

Notes: All dollar figures are in real 2009 dollars. All specifications include as controls state dummies and 1960 black enrollment share. The TSLS regressions in column (3) use the 1960 child poverty rate as an instrument for the 1964 to 1967 change in per-pupil federal revenue. Standard errors (in parentheses) are clustered on county.

*** Significant at the 1 percent level, **Significant at the 5 percent level, * Significant at the 10 percent level. 


\begin{tabular}{|c|c|}
\hline \multicolumn{2}{|c|}{ TO THE INTRODUCTION OF TITLE I } \\
\hline & 1964 to 1969 \\
\hline & $\begin{array}{l}\text { A. } \Delta \text { Per-pupil } \\
\text { Current } \\
\text { Expenditure }\end{array}$ \\
\hline$\Delta$ Per-pupil Federal Revenue, 1964 to 1969 & $\begin{array}{c}0.561 * * * \\
(0.086)\end{array}$ \\
\hline Black Enrollment Share, 1960 & $\begin{array}{c}214.60^{* * *} \\
(54.94)\end{array}$ \\
\hline & $\begin{array}{c}\text { B. } \Delta \text { Per-pupil } \\
\text { Total } \\
\text { Expenditure }\end{array}$ \\
\hline$\Delta$ Per-pupil Federal Revenue, 1964 to 1969 & $\begin{array}{c}0.575 * * * \\
(0.179)\end{array}$ \\
\hline Black Enrollment Share, 1960 & $\begin{array}{c}152.40 \\
(157.40)\end{array}$ \\
\hline First-stage Partial $F$-stat on instrument & 116.8 \\
\hline Number of districts & 621 \\
\hline
\end{tabular}

Notes: All dollar figures are in real 2009 dollars. All specifications include as controls state dummies and 1960 black enrollment share. The 1960 child poverty rate is an instrument for the 1964 to 1969 change in per-pupil federal revenue. Standard errors (in parentheses) are clustered on county. Sample size differs from Table 3 because districts in Georgia and North Carolina did not report total expenditure and are excluded from the balanced panel sample for this table.

*** Significant at the 1 percent level. 


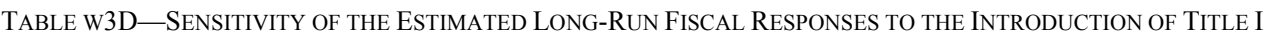
TO PRE-TRENDS IN FISCAL VARIABLES

\begin{tabular}{cccc}
\hline \hline & & $\begin{array}{c}\text { Controlling for } \\
\text { lagged (1961-64) } \\
\text { changes in } \\
\text { dependent } \\
\text { variable }\end{array}$ \\
\hline Baseline & $\begin{array}{c}\text { Counterfactual is } \\
\text { trend from 1961 } \\
\text { to 1964 }\end{array}$ & $\begin{array}{c}\text { (1) } \\
\text { (1) }\end{array}$ & $(2)$ \\
\hline
\end{tabular}

A. $\Delta$ Per-pupil Current Expenditure

$\begin{array}{lccc}\Delta \text { Per-pupil Federal Revenue } & 0.502 * * * & 0.613 * * * & 0.471 * * * \\ & (0.0795) & (0.125) & (0.0779) \\ \text { First-stage Partial F-stat on Instr. } & 245.9 & 227.4 & 245.1\end{array}$

B. $\Delta$ Per-pupil State Revenue

$\Delta$ Per-pupil Federal Revenue

First-stage Partial F-stat on Instr.

$\Delta$ Per-pupil Federal Revenue

First-stage Partial F-stat on Instr.

Number of districts
0.0519

(0.0405)

245.9

C. $\Delta$ Per-pupil Local Revenue

$\begin{array}{ccc}-0.327 * * * & -0.229 * * * & -0.343 * * * \\ (0.0586) & (0.0731) & (0.0601) \\ 245.9 & 227.4 & 240.4 \\ & & \\ 910 & 910 & 910\end{array}$

Notes: This table verifies footnote 21. Changes in fiscal variables correspond to 1964 to 1969 and are in real 2009 dollars. Each column and panel represents a different TSLS regression. Column (1) of this table replicates Column (3) of Table 3 in the paper. All regressions include state dummies and 1960 black enrollment share as controls. The instrument for the change in per-pupil federal revenue is the 1960 child poverty rate. See Appendix A for detailed description of control variables and data sources. Standard errors (in parentheses) are clustered on county.

*** Significant at the 1 percent level. 
TABLE W4-SENSITIVITY OF THE ESTIMATED LONG-RUN FisCAL RESPONSES TO THE INTRODUCTION OF TiTLE I, CONTROLLING FOR 1970 DISSIMILARITY INDEX AND COURT ORDERS

\begin{tabular}{|c|c|c|}
\hline & $\begin{array}{l}\text { Baseline Model for } \\
\text { Subsample with } \\
\text { 1970 Dissimilarity } \\
\text { and Court Orders } \\
\text { (1) }\end{array}$ & $\begin{array}{l}\text { Controlling for } 1970 \\
\text { Dissimilarity and Court } \\
\text { Orders } \\
\text { (2) }\end{array}$ \\
\hline & \multicolumn{2}{|c|}{ A. Per-pupil Current Expenditure } \\
\hline$\Delta$ Per-pupil Federal Revenue & $\begin{array}{c}0.544 * * * \\
(0.0808)\end{array}$ & $\begin{array}{c}0.541 * * * \\
(0.0804)\end{array}$ \\
\hline \multirow[t]{2}{*}{ Root MSE } & 288.6 & 289.0 \\
\hline & \multicolumn{2}{|c|}{ B. Per-pupil State Revenue } \\
\hline$\Delta$ Per-pupil Federal Revenue & $\begin{array}{c}0.0792 * \\
(0.0418)\end{array}$ & $\begin{array}{c}0.0809^{*} \\
(-0.0416)\end{array}$ \\
\hline \multirow[t]{2}{*}{ Root MSE } & 143.3 & 143.3 \\
\hline & \multicolumn{2}{|c|}{ C. Per-pupil Local Revenue } \\
\hline$\Delta$ Per-pupil Federal Revenue & $\begin{array}{c}-0.317 * * * \\
(0.0624)\end{array}$ & $\begin{array}{c}-0.319 * * * \\
(-0.0617)\end{array}$ \\
\hline Root MSE & 220.0 & 220.4 \\
\hline First-stage Partial F-stat on Instr. & 204.2 & 217.2 \\
\hline Number of districts & 853 & 853 \\
\hline
\end{tabular}

Notes: This table verifies a statement made in footnote 30. Changes in fiscal variables correspond to 1964 to 1969 and are in real 2009 dollars. Each column and panel represents a different TSLS regression. Unless otherwise noted, all regressions include state dummies and 1960 black enrollment share as controls. The instrument for the change in per-pupil federal revenue is the 1960 child poverty rate. See Appendix A for detailed description of control variables and data sources. Standard errors (in parentheses) are clustered on county.

*** Significant at the 1 percent level

**Significant at the 5 percent level

* Significant at the 10 percent level. 
TABLE W5A-THE DESEgREGATION RESPONSE TO THE INTRODUCTION OF TITLE I AND HETEROGENEITY IN THE FISCAL AND DESEGREGATION RESPONSE TO THE INTRODUCTION OF TITLE I BY SCOPE FOR LOCAL OFFSET,

PREDICTING PER-PUPIL LOCAL REVENUE IN 1969 ON THE BASIS OF PRE-ESEA TRENDS IN THE NATURAL LOG OF PER-PUPIL LOCAL REVENUE

\begin{tabular}{|c|c|c|c|c|}
\hline \multirow[b]{2}{*}{ Dependent Variable: } & \multicolumn{3}{|c|}{$\Delta(1964$ to 1969$)$ in Per-pupil } & \multirow{2}{*}{$\begin{array}{c}1970 \\
\text { Dissimilarity } \\
\text { Index } \\
(4)\end{array}$} \\
\hline & $\begin{array}{c}\text { Current } \\
\text { Expenditure } \\
\text { (1) }\end{array}$ & $\begin{array}{c}\text { State } \\
\text { Revenue } \\
\text { (2) }\end{array}$ & $\begin{array}{c}\text { Local } \\
\text { Revenue } \\
(3)\end{array}$ & \\
\hline & \multicolumn{4}{|c|}{$\begin{array}{l}\text { B. By Scope for Local Offset } \\
\text { 1. Districts with Low Scope for Offset }\end{array}$} \\
\hline $\begin{array}{l}\Delta \text { Per-pupil Federal Revenue, } \\
1964 \text { to } 1969\end{array}$ & $\begin{array}{c}0.893 * * * \\
(0.160)\end{array}$ & $\begin{array}{c}0.017 \\
(0.087)\end{array}$ & $\begin{array}{l}-0.0009 \\
(0.102)\end{array}$ & $\begin{array}{l}-9.54 \mathrm{e}-05 \\
(0.00012)\end{array}$ \\
\hline First-stage Partial $F$-stat on Instr. & 37.4 & 37.4 & 37.4 & 32.8 \\
\hline \multirow[t]{2}{*}{ Number of districts } & 227 & 227 & 227 & 206 \\
\hline & \multicolumn{4}{|c|}{ 2. Other Districts } \\
\hline $\begin{array}{l}\Delta \text { Per-pupil Federal Revenue, } \\
1964 \text { to } 1969\end{array}$ & $\begin{array}{c}0.207 \\
(0.154)\end{array}$ & $\begin{array}{c}0.020 \\
(0.079)\end{array}$ & $\begin{array}{c}-0.560^{* * *} \\
(0.127)\end{array}$ & $\begin{array}{l}-4.84 \mathrm{e}-05 \\
(9.04 \mathrm{e}-05)\end{array}$ \\
\hline First-stage Partial F-stat on Instr. & 84.98 & 84.98 & 84.98 & 72.42 \\
\hline \multirow[t]{2}{*}{ Number of districts } & 683 & 683 & 683 & 647 \\
\hline & \multicolumn{4}{|c|}{ 3. Difference } \\
\hline $\begin{array}{c}\Delta \text { Per-pupil Federal Revenue } \\
\text { x Low Scope for Offset }\end{array}$ & $\begin{array}{c}0.686 * * * \\
(0.220)\end{array}$ & $\begin{array}{l}-0.003 \\
(0.117)\end{array}$ & $\begin{array}{c}0.559 * * * \\
(0.162)\end{array}$ & $\begin{array}{l}4.70 \mathrm{e}-05 \\
(0.00015)\end{array}$ \\
\hline Number of districts & 910 & 910 & 910 & 853 \\
\hline
\end{tabular}

Notes: This table verifies a statement made in footnote 27. All dollar figures are in real 2009 dollars. Each column and panel presents coefficient estimates from a TSLS regression. All regressions include state dummies, 1960 black enrollment share, $\ln (1960$ district enrollment), an indicator that the district is in one of the 300 poorest counties in 1960, and indicators for quintiles of the Thurmond vote share. In Panels B1 and B2, the 1964 to 1969 change in per-pupil federal revenue is instrumented with the 1960 child poverty rate. In Panel B3, the 1964 to 1969 change in per-pupil federal revenue and the 1964 to 1969 change in per-pupil federal revenue interacted with the low scope for offset indicator are instrumented with the 1960 child poverty rate and the 1960 child poverty rate interacted with low scope for offset indicator. A district is classified is having "low scope for local offset" if it is ranked in the top quartile of the ratio of the predicted per-pupil Title I grant in 1969 to predicted per-pupil local revenue in 1969, the latter is the prediction given the district-specific linear trend in the natural log of per-pupil local revenue over 1961 to 1964. Standard errors (in parentheses) are clustered on county.

*** Significant at the 1 percent level. 
TABLE W5B - THE DESEGREGATION RESPONSE TO THE INTRODUCTION OF TITLE I AND HETEROGENEITY IN THE FISCAL AND DESEGREGATION RESPONSE TO THE INTRODUCTION OF TITLE I BY SCOPE FOR LOCAL OFFSET, WHERE DENOMINATOR IS PREDICTED PER-PUPIL STATE AND LOCAL COMBINED REVENUE (RATHER THAN SOLELY LOCAL REVENUE)

\begin{tabular}{|c|c|c|c|c|}
\hline \multirow[b]{2}{*}{ Dependent Variable: } & \multicolumn{3}{|c|}{$\Delta(1964$ to 1969$)$ in Per-pupil } & \multirow{2}{*}{$\begin{array}{c}1970 \\
\text { Dissimilarity } \\
\text { Index } \\
(4)\end{array}$} \\
\hline & $\begin{array}{c}\text { Current } \\
\text { Expenditure } \\
(1) \\
\end{array}$ & $\begin{array}{c}\text { State } \\
\text { Revenue } \\
(2)\end{array}$ & $\begin{array}{c}\text { Local } \\
\text { Revenue } \\
(3)\end{array}$ & \\
\hline & \multicolumn{4}{|c|}{$\begin{array}{l}\text { B. By Scope for Local Offset } \\
\text { 1. Districts with Low Scope for Offset }\end{array}$} \\
\hline $\begin{array}{l}\Delta \text { Per-pupil Federal Revenue, } \\
1964 \text { to } 1969\end{array}$ & $\begin{array}{l}0.918 * * * \\
(0.213)\end{array}$ & $\begin{array}{l}0.0141 \\
(0.108)\end{array}$ & $\begin{array}{l}0.0069 \\
(0.102)\end{array}$ & $\begin{array}{l}0.00022 * \\
(0.00013)\end{array}$ \\
\hline First-stage Partial F-stat on Instr. & 17.43 & 17.43 & 17.43 & 16.07 \\
\hline \multirow{2}{*}{ Number of districts } & 227 & 227 & 227 & 210 \\
\hline & \multicolumn{4}{|c|}{ 2. Other Districts } \\
\hline $\begin{array}{l}\Delta \text { Per-pupil Federal Revenue, } \\
\quad 1964 \text { to } 1969\end{array}$ & $\begin{array}{l}0.233^{*} \\
(0.130)\end{array}$ & $\begin{array}{c}0.002 \\
(0.065)\end{array}$ & $\begin{array}{c}-0.511 * * * \\
(0.105)\end{array}$ & $\begin{array}{l}7.96 \mathrm{e}-05 \\
(7.92 \mathrm{e}-05)\end{array}$ \\
\hline First-stage Partial F-stat on Instr. & 198.8 & 198.8 & 198.8 & 175.6 \\
\hline \multirow[t]{2}{*}{ Number of districts } & 683 & 683 & 683 & 643 \\
\hline & \multicolumn{4}{|c|}{ 3. Difference } \\
\hline $\begin{array}{c}\Delta \text { Per-pupil Federal Revenue } \\
\text { x Low Scope for Offset }\end{array}$ & $\begin{array}{c}0.684 * * * \\
(0.246)\end{array}$ & $\begin{array}{l}0.0124 \\
(0.125)\end{array}$ & $\begin{array}{c}0.518 * * * \\
(0.146)\end{array}$ & $\begin{array}{c}0.00014 \\
(0.00015)\end{array}$ \\
\hline Number of districts & 910 & 910 & 910 & 853 \\
\hline
\end{tabular}

Notes: This table verifies a statement made in footnote 27. All dollar figures are in real 2009 dollars. Each column and panel presents coefficient estimates from a TSLS regression. All regressions include state dummies, 1960 black enrollment share, $\ln (1960$ district enrollment), an indicator that the district is in one of the 300 poorest counties in 1960, and indicators for quintiles of the Thurmond vote share. In Panels B1 and B2, the 1964 to 1969 change in per-pupil federal revenue is instrumented with the 1960 child poverty rate. In Panel B3, the 1964 to 1969 change in per-pupil federal revenue and the 1964 to 1969 change in per-pupil federal revenue interacted with the low scope for offset indicator are instrumented with the 1960 child poverty rate and the 1960 child poverty rate interacted with low scope for offset indicator. A district is classified is having "low scope for local offset" if it is ranked in the top quartile of the ratio of the predicted per-pupil Title I grant in 1969 to predicted per-pupil combined local and state revenue in 1969, the latter is the prediction of combined local and state revenue given the district-specific linear trend over 1961 to 1964. Standard errors (in parentheses) are clustered on county.

*** Significant at the 1 percent level

**Significant at the 5 percent level

* Significant at the 10 percent level. 
TABLE W5C - THE DESEgREgATION RESPONSE TO THE INTRODUCTION OF TITLE I AND HETEROGENEITY IN THE FISCAL AND DESEGREGATION RESPONSE TO THE INTRODUCTION OF TITLE I BY SCOPE FOR LOCAL OFFSET, SPLITTING SAMPLE AT MEDIAN

\begin{tabular}{|c|c|c|c|c|}
\hline \multirow[b]{2}{*}{ Dependent Variable: } & \multicolumn{3}{|c|}{$\Delta(1964$ to 1969$)$ in Per-pupil } & \multirow{2}{*}{$\begin{array}{c}1970 \\
\text { Dissimilarity } \\
\text { Index } \\
(4) \\
\end{array}$} \\
\hline & $\begin{array}{c}\text { Current } \\
\text { Expenditure } \\
(1) \\
\end{array}$ & $\begin{array}{c}\text { State } \\
\text { Revenue } \\
(2)\end{array}$ & $\begin{array}{c}\text { Local } \\
\text { Revenue } \\
(3) \\
\end{array}$ & \\
\hline & \multicolumn{4}{|c|}{$\begin{array}{l}\text { B. By Scope for Local Offset } \\
\text { s with Low Scope for Offset Split at Median }\end{array}$} \\
\hline $\begin{array}{l}\Delta \text { Per-pupil Federal Revenue, } \\
1964 \text { to } 1969\end{array}$ & $\begin{array}{c}0.798^{* * *} \\
(0.126)\end{array}$ & $\begin{array}{c}0.0008 \\
(0.0619)\end{array}$ & $\begin{array}{l}-0.0477 \\
(0.0747)\end{array}$ & $\begin{array}{c}0.000145^{*} \\
(0.0000841)\end{array}$ \\
\hline First-stage Partial F-stat on Instr. & 78.93 & 78.93 & 78.93 & 67.81 \\
\hline \multirow[t]{2}{*}{ Number of districts } & 455 & 455 & 455 & 419 \\
\hline & \multicolumn{4}{|c|}{ 2. Other Districts } \\
\hline $\begin{array}{l}\Delta \text { Per-pupil Federal Revenue, } \\
1964 \text { to } 1969\end{array}$ & $\begin{array}{l}0.304^{*} \\
(0.178)\end{array}$ & $\begin{array}{l}0.181 * \\
(0.099)\end{array}$ & $\begin{array}{c}-0.755^{* * *} \\
(0.198)\end{array}$ & $\begin{array}{l}0.0000887 \\
(0.00013)\end{array}$ \\
\hline First-stage Partial F-stat on Instr. & 96.19 & 96.19 & 96.19 & 91.65 \\
\hline \multirow[t]{2}{*}{ Number of districts } & 455 & 455 & 455 & 434 \\
\hline & \multicolumn{4}{|c|}{ 3. Difference } \\
\hline $\begin{array}{c}\Delta \text { Per-pupil Federal Revenue } \\
\text { x Low Scope for Offset }\end{array}$ & $\begin{array}{c}0.494^{* *} \\
(0.218)\end{array}$ & $\begin{array}{l}-0.180 \\
(0.116)\end{array}$ & $\begin{array}{c}0.707 * * * \\
(0.213)\end{array}$ & $\begin{array}{l}0.0000564 \\
(0.000152)\end{array}$ \\
\hline Number of districts & 910 & 910 & 910 & 853 \\
\hline
\end{tabular}

Notes: This table is analogous to Panel B of Table 5 in the paper, but instead defining low scope for offset to be the top half rather than top 25 percent of districts. All dollar figures are in real 2009 dollars. Each column and panel presents coefficient estimates from a TSLS regression. All regressions include state dummies, 1960 black enrollment share, $\ln (1960$ district enrollment), an indicator that the district is in one of the 300 poorest counties in 1960, and indicators for quintiles of the Thurmond vote share. In Panels B1 and B2, the 1964 to 1969 change in per-pupil federal revenue is instrumented with the 1960 child poverty rate. In Panel B3, the 1964 to 1969 change in per-pupil federal revenue and the 1964 to 1969 change in per-pupil federal revenue interacted with the low scope for offset indicator are instrumented with the 1960 child poverty rate and the 1960 child poverty rate interacted with low scope for offset indicator. A district is classified is having "low scope for local offset" if it is ranked in the top half of the distribution of the ratio of the predicted per-pupil Title I grant in 1969 to predicted per-pupil local revenue in 1969, the latter is the prediction given the districtspecific linear trend over 1961 to 1964. Standard errors (in parentheses) are clustered on county.

*** Significant at the 1 percent level.

**Significant at the 5 percent level.

* Significant at the 10 percent level. 
TABLE W5D - THE DESEGREGATION RESPONSE TO THE INTRODUCTION OF TITLE I AND HETEROGENEITY IN THE FISCAL AND DESEGREGATION RESPONSE TO THE INTRODUCTION OF TITLE I BY SCOPE FOR LOCAL OFFSET AND BY BLACK SHARE

\begin{tabular}{|c|c|c|c|}
\hline \multirow[b]{2}{*}{ Dependent Variable: } & \multicolumn{3}{|c|}{$\begin{array}{c}\text { Difference across District Types in } \\
\Delta(1964 \text { to } 1969) \text { Per-pupil }\end{array}$} \\
\hline & $\begin{array}{c}\text { Current } \\
\text { Expenditure } \\
(1)\end{array}$ & $\begin{array}{c}\text { State } \\
\text { Revenue } \\
\text { (2) }\end{array}$ & $\begin{array}{c}\text { Local } \\
\text { Revenue } \\
(3)\end{array}$ \\
\hline $\begin{array}{c}\Delta \text { Per-pupil Federal Revenue } \\
\text { x Low Scope for Offset }\end{array}$ & $\begin{array}{c}0.697 * * \\
(0.310)\end{array}$ & $\begin{array}{c}0.114 \\
(0.163)\end{array}$ & $\begin{array}{l}0.662 * * \\
(0.272)\end{array}$ \\
\hline $\begin{array}{l}\Delta \text { Per-pupil Federal Revenue } \\
\text { x High Black Share }\end{array}$ & $\begin{array}{c}0.208 \\
(0.366)\end{array}$ & $\begin{array}{l}-0.046 \\
(0.187)\end{array}$ & $\begin{array}{l}-0.139 \\
(0.350)\end{array}$ \\
\hline Number of districts & 910 & 910 & 910 \\
\hline
\end{tabular}

Notes: This table verifies a statement made in footnote 29. It is analogous in set-up to Panel B3 of Table 5 in the paper, with the addition of the interaction between high black share (defined as being in the top quartile of the 1960 black enrollment share) and the change in per-pupil federal revenue. All dollar figures are in real 2009 dollars. Each column and panel presents coefficient estimates from a TSLS regression. All regressions include state dummies, 1960 black enrollment share, $\ln (1960$ district enrollment), an indicator that the district is in one of the 300 poorest counties in 1960, and indicators for quintiles of the Thurmond vote share, all interacted with dummies for low scope for offset and high black share. The 1964 to 1969 change in per-pupil federal revenue and the 1964 to 1969 change in per-pupil federal revenue interacted with the low scope for offset and high black share indicators are instrumented with the1960 child poverty rate and the 1960 child poverty rate interacted with low scope for offset and high black share indicators. A district is classified is having "low scope for local offset" if it is ranked above the $75^{\text {th }}$ percentile of the ratio of the predicted per-pupil Title I grant in 1969 to predicted per-pupil local revenue in 1969, the latter is the prediction given the district-specific linear trend over 1961 to 1964 . Standard errors (in parentheses) are clustered on county.

**Significant at the 5 percent level. 
TABLE W5E-THE DeSEgREgATION RESPONSE TO THE INTRODUCTION OF TITLE I AND HETEROGENEITY IN THE FISCAL AND DESEGREGATION RESPONSE TO THE INTRODUCTION OF TITLE I BY SCOPE FOR LOCAL OFFSET AND BY POVERTY SHARE

\begin{tabular}{|c|c|c|c|}
\hline \multirow[b]{2}{*}{ Dependent Variable: } & \multicolumn{3}{|c|}{$\begin{array}{c}\text { Difference across District Types in } \\
\Delta(1964 \text { to } 1969) \text { Per-pupil }\end{array}$} \\
\hline & $\begin{array}{c}\text { Current } \\
\text { Expenditure } \\
(1)\end{array}$ & $\begin{array}{c}\text { State } \\
\text { Revenue } \\
(2)\end{array}$ & $\begin{array}{c}\text { Local } \\
\text { Revenue } \\
(3)\end{array}$ \\
\hline $\begin{array}{l}\Delta \text { Per-pupil Federal Revenue } \\
\text { x Low Scope for Offset }\end{array}$ & $\begin{array}{c}0.319 \\
(0.465)\end{array}$ & $\begin{array}{l}-0.122 \\
(0.225)\end{array}$ & $\begin{array}{c}0.226 \\
(0.213)\end{array}$ \\
\hline $\begin{array}{l}\Delta \text { Per-pupil Federal Revenue } \\
\text { x High Poverty Rate }\end{array}$ & $\begin{array}{c}0.308 \\
(0.481)\end{array}$ & $\begin{array}{c}0.212 \\
(0.220)\end{array}$ & $\begin{array}{c}0.339 \\
(0.219)\end{array}$ \\
\hline Number of districts & 910 & 910 & 910 \\
\hline $\begin{array}{l}p \text {-value on joint significance of } \\
\text { interactions }\end{array}$ & 0.042 & 0.58 & 0.00164 \\
\hline
\end{tabular}

Notes: This table verifies statements made in footnote 29. It is analogous in set-up to Panel B3 of Table 5 in the paper, with the addition of the interaction between high poverty rate (defined as being in the top quartile of the 1960 child poverty rate) and the change in per-pupil federal revenue. All dollar figures are in real 2009 dollars. Each column and panel presents coefficient estimates from a TSLS regression. All regressions include state dummies, 1960 black enrollment share, $\ln (1960$ district enrollment), an indicator that the district is in one of the 300 poorest counties in 1960, and indicators for quintiles of the Thurmond vote share, all interacted with dummies for low scope for offset and high poverty rate. The 1964 to 1969 change in per-pupil federal revenue and the 1964 to 1969 change in per-pupil federal revenue interacted with the low scope for offset and high poverty rate indicators are instrumented with the 1960 child poverty rate and the 1960 child poverty rate interacted with low scope for offset and high poverty rate indicators, respectively. A district is classified is having "low scope for local offset" if it is ranked above the $75^{\text {th }}$ percentile of the ratio of the predicted per-pupil Title I grant in 1969 to predicted per-pupil local revenue in 1969, the latter is the prediction given the district-specific linear trend over 1961 to 1964 . Standard errors (in parentheses) are clustered on county. 
TABLE W5F-THE DESEGREGATION RESPONSE TO THE INTRODUCTION OF TITLE I AND HETEROGENEITY IN THE FISCAL AND DESEGREGATION RESPONSE TO THE INTRODUCTION OF TITLE I BY SCOPE FOR LOCAL OFFSET SEE COLUMN (4) HERE FOR 1969 RATHER THAN 1970 DISSIMILARITY

\begin{tabular}{|c|c|c|c|c|}
\hline \multirow[b]{2}{*}{ Dependent Variable: } & \multicolumn{3}{|c|}{$\Delta(1964$ to 1969$)$ in Per-pupil } & \multirow{2}{*}{$\begin{array}{c}1969 \\
\text { Dissimilarity } \\
\text { Index } \\
(4)\end{array}$} \\
\hline & $\begin{array}{c}\text { Current } \\
\text { Expenditure } \\
(1) \\
\end{array}$ & $\begin{array}{c}\text { State } \\
\text { Revenue } \\
(2)\end{array}$ & $\begin{array}{c}\text { Local } \\
\text { Revenue } \\
(3) \\
\end{array}$ & \\
\hline & \multicolumn{4}{|c|}{ A. Full Sample } \\
\hline $\begin{array}{l}\Delta \text { Per-pupil Federal Revenue, } \\
1964 \text { to } 1969\end{array}$ & $\begin{array}{l}0.464 * * * \\
(0.0982)\end{array}$ & $\begin{array}{c}0.0529 \\
(0.0492)\end{array}$ & $\begin{array}{c}-0.321^{* * *} \\
(0.0741)\end{array}$ & $\begin{array}{l}-5.77 \mathrm{e}-05 \\
(0.00014)\end{array}$ \\
\hline First-stage Partial F-stat on Instr. & 168.9 & 168.9 & 168.9 & 104.1 \\
\hline \multirow[t]{2}{*}{ Number of districts } & 910 & 910 & 910 & 647 \\
\hline & \multicolumn{4}{|c|}{ B. By Scope for Local Offset } \\
\hline $\begin{array}{l}\Delta \text { Per-pupil Federal Revenue, } \\
1964 \text { to } 1969\end{array}$ & $\begin{array}{c}0.881 * * * \\
(0.167)\end{array}$ & $\begin{array}{c}0.0101 \\
(0.0886)\end{array}$ & $\begin{array}{l}-0.0262 \\
(0.101)\end{array}$ & $\begin{array}{l}-9.59 \mathrm{e}-05 \\
(0.00026)\end{array}$ \\
\hline First-stage Partial F-stat on Instr. & 35.29 & 35.29 & 35.29 & 47.72 \\
\hline \multirow[t]{2}{*}{ Number of districts } & 227 & 227 & 227 & 160 \\
\hline & \multicolumn{4}{|c|}{ 2. Other Districts } \\
\hline $\begin{array}{l}\Delta \text { Per-pupil Federal Revenue, } \\
1964 \text { to } 1969\end{array}$ & $\begin{array}{c}0.208 \\
(0.154)\end{array}$ & $\begin{array}{c}0.0326 \\
(0.0777)\end{array}$ & $\begin{array}{c}-0.564 * * * \\
(0.127)\end{array}$ & $\begin{array}{l}0.000208 \\
(0.00022)\end{array}$ \\
\hline First-stage Partial F-stat on Instr. & 86.20 & 86.20 & 86.20 & 45.93 \\
\hline \multirow[t]{2}{*}{ Number of districts } & 683 & 683 & 683 & 487 \\
\hline & \multicolumn{4}{|c|}{ 3. Difference } \\
\hline $\begin{array}{c}\Delta \text { Per-pupil Federal Revenue } \\
\text { x Low Scope for Offset }\end{array}$ & $\begin{array}{c}0.673 * * * \\
(0.226)\end{array}$ & $\begin{array}{l}-0.0225 \\
(0.117)\end{array}$ & $\begin{array}{c}0.538 * * * \\
(0.161)\end{array}$ & $\begin{array}{c}0.0003 \\
(0.0003)\end{array}$ \\
\hline Number of districts & 910 & 910 & 910 & 647 \\
\hline
\end{tabular}

Notes: This table verifies a statement made in footnote 30. All dollar figures are in real 2009 dollars. Each column and panel presents coefficient estimates from a TSLS regression. All regressions include state dummies, 1960 black enrollment share, $\ln (1960$ district enrollment), an indicator that the district is in one of the 300 poorest counties in 1960, and indicators for quintiles of the Thurmond vote share. In Panels A, B1, and B2, the 1964 to 1969 change in per-pupil federal revenue is instrumented with the 1960 child poverty rate. In Panel B3, the 1964 to 1969 change in per-pupil federal revenue and the 1964 to 1969 change in per-pupil federal revenue interacted with the low scope for offset indicator are instrumented with the 1960 child poverty rate and the 1960 child poverty rate interacted with low scope for offset indicator. A district is classified is having "low scope for local offset" if it is ranked in the top quartile of the ratio of the predicted per-pupil Title I grant in 1969 to predicted per-pupil local revenue in 1969, the latter is the prediction given the district-specific linear trend over 1961 to 1964. Standard errors (in parentheses) are clustered on county.

*** Significant at the 1 percent level. 
TABle W7A - TSLS Estimates of the EFfect of School SPending On High School Dropout by Race SHOWING DiRECT EFFECT OF 1960 CHILD POVERTY RATE

\begin{tabular}{|c|c|c|c|}
\hline$\Delta$ White High School Dropout (\%), 1960-70: & $\begin{array}{c}\text { Ages } 18-19 \\
(1)\end{array}$ & $\begin{array}{c}\text { Ages } 18-19 \\
(2)\end{array}$ & $\begin{array}{c}\text { Ages } 25+ \\
\text { (3) }\end{array}$ \\
\hline \multirow[t]{2}{*}{ Mean of Dependent Variable } & -10.0 & -10.0 & -7.7 \\
\hline & \multicolumn{3}{|c|}{$\begin{array}{l}\text { Instrument is } 1960 \text { Child Poverty Rate } \\
\text { x Low Scope for Offset (Full Sample) }\end{array}$} \\
\hline $\begin{array}{l}\Delta \text { Per-pupil Current Expenditure (\$100s), } \\
1964 \text { to } 1969\end{array}$ & $\begin{array}{l}-5.47^{*} \\
(2.80)\end{array}$ & $\begin{array}{l}-6.28^{*} \\
(3.72)\end{array}$ & $\begin{array}{c}0.48 \\
(0.56)\end{array}$ \\
\hline 1960 Child Poverty Rate & $\begin{array}{l}23.31 \\
(20.97)\end{array}$ & $\begin{array}{l}17.72 \\
(23.00)\end{array}$ & $\begin{array}{c}0.82 \\
(3.80)\end{array}$ \\
\hline Root MSE & 17.26 & 19.31 & 3.63 \\
\hline First-stage Partial $F$-stat on instr. & 4.826 & 3.536 & 4.346 \\
\hline Number of counties & 647 & 646 & 646 \\
\hline$\Delta$ Black High School Dropout (\%), 1960-70: & $\begin{array}{c}\text { Ages } 18-19 \\
(4)\end{array}$ & $\begin{array}{c}\text { Ages } 18-19 \\
(5)\end{array}$ & $\begin{array}{c}\text { Ages } 25+ \\
(6)\end{array}$ \\
\hline \multirow[t]{2}{*}{ Mean of Dependent Variable } & -14.1 & -14.1 & -7.9 \\
\hline & \multicolumn{3}{|c|}{$\begin{array}{l}\text { Instrument is } 1960 \text { Child Poverty Rate } \\
\text { x Low Scope for Offset (Full Sample) }\end{array}$} \\
\hline $\begin{array}{l}\Delta \text { Per-pupil Current Expenditure }(\$ 100 \text { s), } \\
1964 \text { to } 1969\end{array}$ & $\begin{array}{c}0.17 \\
(2.01)\end{array}$ & $\begin{array}{c}0.98 \\
(1.82)\end{array}$ & $\begin{array}{l}-0.29 \\
(0.46)\end{array}$ \\
\hline 1960 Child Poverty Rate & $\begin{array}{c}5.71 \\
(14.20)\end{array}$ & $\begin{array}{c}2.33 \\
(11.90)\end{array}$ & $\begin{array}{l}8.61 * * \\
(4.22)\end{array}$ \\
\hline Root MSE & 8.159 & 8.569 & 2.430 \\
\hline First-stage Partial F-stat on instr. & 3.026 & 4.081 & 3.180 \\
\hline Number of counties & 605 & 604 & 541 \\
\hline Additional Controls? & & $\mathrm{X}$ & \\
\hline
\end{tabular}

Notes: The change in per-pupil current expenditure is in hundreds of real 2009 dollars. Each column and panel presents estimates from a different regression. All regressions are weighted by the race-specific 1960 county population of the relevant age group. All regressions include as controls state dummies, 1960 black enrollment share, $\ln (1960$ district enrollment), an indicator that the county was one of the 300 poorest counties in 1960, indicators for quintiles of the Thurmond county vote share, and race-specific 1960 high school dropout rates of the relevant age group. These controls are also interacted with the low scope for offset indicator. "Additional controls" include changes in transfers to the county for other federal programs from 1962-69, also interacted with the low scope for offset indicator. Attention is restricted to counties where districts in our estimation sample represent at least 90 percent of total county enrollment in 1960 . Standard errors (in parentheses) are heteroskedasticity robust.

** Significant at the 5 percent level

* Significant at the 10 percent level. 
TABle W7B - TSLS Estimates of the EFFECT OF School SPENDing ON High SCHOOL Dropout By RACE CONTROLLING FOR 1950-60 CHANGE IN SCHOOL ENROLLMENT RATE OF 15-16 YEAR OLDS

\begin{tabular}{|c|c|c|c|}
\hline$\Delta$ White High School Dropout (\%), 1960-70: & $\begin{array}{c}\text { Ages } 18-19 \\
(1)\end{array}$ & $\begin{array}{c}\text { Ages } 18-19 \\
(2)\end{array}$ & $\begin{array}{c}\text { Ages } 25+ \\
(3)\end{array}$ \\
\hline \multirow[t]{2}{*}{ Mean of Dependent Variable } & -10.0 & -10.0 & -7.7 \\
\hline & \multicolumn{3}{|c|}{$\begin{array}{l}\text { A. Instrument is } 1960 \text { Child Poverty Rate } \\
\text { (Sample is Counties with Low Scope for Local Offset) }\end{array}$} \\
\hline $\begin{array}{l}\Delta \text { Per-pupil Current Expenditure }(\$ 100 \text { s), } \\
1964 \text { to } 1969\end{array}$ & $\begin{array}{c}-3.46^{* * *} \\
(1.27)\end{array}$ & $\begin{array}{l}-4.20 * * \\
(1.64)\end{array}$ & $\begin{array}{c}0.55 \\
(0.43)\end{array}$ \\
\hline Root MSE & 15.04 & 16.57 & 4.257 \\
\hline First-stage Partial $F$-stat on instrument & 13.01 & 11.11 & 17.9 \\
\hline \multirow[t]{2}{*}{ Number of counties } & 152 & 152 & 152 \\
\hline & \multicolumn{3}{|c|}{$\begin{array}{l}\text { B. Instrument is } 1960 \text { Child Poverty Rate } \\
\text { x Low Scope for Offset (Full Sample) }\end{array}$} \\
\hline $\begin{array}{l}\Delta \text { Per-pupil Current Expenditure }(\$ 100 \text { s), } \\
1964 \text { to } 1969\end{array}$ & $\begin{array}{l}-5.03 * \\
(2.58)\end{array}$ & $\begin{array}{l}-5.20 * \\
(2.70)\end{array}$ & $\begin{array}{c}0.46 \\
(0.56)\end{array}$ \\
\hline Root MSE & 15.87 & 16.1 & 3.61 \\
\hline First-stage Partial F-stat on instr. & 4.542 & 4.696 & 4.229 \\
\hline Number of counties & 642 & 642 & 642 \\
\hline$\Delta$ Black High School Dropout (\%), 1960-70: & $\begin{array}{c}\text { Ages } 18-19 \\
(4)\end{array}$ & $\begin{array}{c}\text { Ages } 18-19 \\
(5)\end{array}$ & $\begin{array}{c}\text { Ages } 25+ \\
(6)\end{array}$ \\
\hline \multirow[t]{2}{*}{ Mean of Dependent Variable } & -14.1 & -14.1 & -7.9 \\
\hline & \multicolumn{3}{|c|}{$\begin{array}{l}\text { A. Instrument is } 1960 \text { Child Poverty Rate } \\
\text { (Sample is Counties with Low Scope for Local Offset) }\end{array}$} \\
\hline $\begin{array}{l}\Delta \text { Per-pupil Current Expenditure }(\$ 100 \text { s), } \\
1964 \text { to } 1969\end{array}$ & $\begin{array}{c}0.66 \\
(1.06)\end{array}$ & $\begin{array}{c}1.17 \\
(1.08)\end{array}$ & $\begin{array}{c}0.38 \\
(0.23)\end{array}$ \\
\hline Root MSE & 10.32 & 10.54 & 2.35 \\
\hline First-stage Partial F-stat on instrument & 14.25 & 14.85 & 16.34 \\
\hline \multirow[t]{2}{*}{ Number of counties } & 135 & 135 & 124 \\
\hline & \multicolumn{3}{|c|}{$\begin{array}{l}\text { B. Instrument is } 1960 \text { Child Poverty Rate } \\
\text { x Low Scope for Offset (Full Sample) }\end{array}$} \\
\hline $\begin{array}{l}\Delta \text { Per-pupil Current Expenditure }(\$ 100 \text { s), } \\
1964 \text { to } 1969\end{array}$ & $\begin{array}{c}0.13 \\
(2.02)\end{array}$ & $\begin{array}{c}0.92 \\
(1.77)\end{array}$ & $\begin{array}{l}-0.25 \\
(0.43)\end{array}$ \\
\hline Root MSE & 8.176 & 8.531 & 2.394 \\
\hline First-stage Partial $F$-stat on instr. & 3.216 & 4.492 & 3.953 \\
\hline Number of counties & 601 & 601 & 539 \\
\hline Additional Controls? & & $\mathrm{X}$ & \\
\hline
\end{tabular}

Notes: The change in per-pupil current expenditure is in hundreds of real 2009 dollars. Each column and panel presents estimates from a different regression. All regressions are weighted by the race-specific 1960 county population of the relevant age group. All regressions include as controls state dummies, 1960 black enrollment share, $\ln$ (1960 district enrollment), an indicator that the county was one of the 300 poorest counties in 1960 , indicators for quintiles of the Thurmond county vote share, race-specific 1960 high school dropout rates of the relevant age group, and the 1950-60 change in the enrollment rate of 16-17 year olds (overall); in Panel B, these controls are interacted with the low scope for offset indicator. "Additional controls" include changes in transfers to the county for other federal programs from 1962-69, which are interacted with the low scope for offset indicator in Panel B. Throughout, attention is restricted to counties where districts in our estimation sample represent at least 90 percent of total county enrollment in 1960. Standard errors (in parentheses) are heteroskedasticity robust. 
*** Significant at the 1 percent level.

**Significant at the 5 percent level.

* Significant at the 10 percent level. 
TABLE W7C - TSLS ESTIMATES OF THE EFFECT OF SCHOOL SPENDING 1964-69 ON 1950-60 CHANGE IN OVERALL SCHOOL ENROLLMENT RATE OF 16-17 YEAR OLDS

\begin{tabular}{|c|c|c|}
\hline & $\begin{array}{c}\text { Specification in } \\
\text { Column (1) of } \\
\text { Table } 7 \\
\end{array}$ & $\begin{array}{c}\text { Specification in } \\
\text { Column (4) of } \\
\text { Table } 7 \\
\end{array}$ \\
\hline & \multicolumn{2}{|c|}{$\begin{array}{l}\text { A. Instrument is } 1960 \text { Child Poverty } \\
\text { Rate (Sample is Counties with Low } \\
\text { Scope for Local Offset) }\end{array}$} \\
\hline $\begin{array}{l}\Delta \text { Per-pupil Current Expenditure }(\$ 100 \text { s), } \\
1964 \text { to } 1969\end{array}$ & $\begin{array}{l}-0.005 \\
(0.783)\end{array}$ & $\begin{array}{c}0.114 \\
(0.710)\end{array}$ \\
\hline Root MSE & 8.029 & 6.343 \\
\hline First-stage Partial F-stat on instrument & 16.15 & 13.53 \\
\hline \multirow[t]{2}{*}{ Number of counties } & 152 & 138 \\
\hline & \multicolumn{2}{|c|}{$\begin{array}{c}\text { B. Instrument is } 1960 \text { Child Poverty } \\
\text { Rate x Low Scope for Offset (Full } \\
\text { Sample) }\end{array}$} \\
\hline $\begin{array}{l}\Delta \text { Per-pupil Current Expenditure (\$100s), } \\
\quad 1964 \text { to } 1969\end{array}$ & $\begin{array}{l}-0.888 \\
(1.342)\end{array}$ & $\begin{array}{l}-1.089 \\
(1.735)\end{array}$ \\
\hline Root MSE & 6.296 & 6.105 \\
\hline First-stage Partial $F$-stat on instr. & 4.826 & 3.026 \\
\hline Number of counties & 642 & 611 \\
\hline
\end{tabular}

Notes: The change in per-pupil current expenditure is in hundreds of real 2009 dollars. See Table 7 notes for descriptions of the column (1) and column (4) specifications. 